従業員計 2,113 名を対象に施行した結果からここらした 自己評価式抑らつ尺度の有効性について検討を加えた。

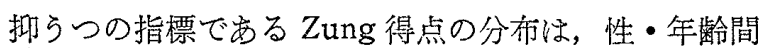
で有意な差があり，非管理職群，未婚群，6力月以内の 職場移動群で高值であった。また，職種間の差よりむし

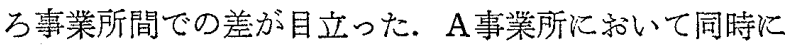
施行したアンケートを用い，正常人集団におけるZung 得点に関与する因子を調べるため，林の数量化 I， III類 による解析を行った，その結果，「身体的健康感」和よ び「任事上の不安感」といった要素との関連が強いこと がわかった.Zung 得点 51 点以上の者 79 名中 70 名に 対し医師による直接面接によって，DSM-IIIによる評価 を行った。. 精神科疾患は 9 例であり，ちちうつ病例 1 名, 職場不適応症 4 名であった. Zung 得点 54 点以下 では大部分が身体的愁訴や疲労感のみの例であり，得点 が上るに従って軽度の抑らつから「問題例」の此率が増 大する. スクリーニング・テストとして考党た場合， Zung 得点のみで実用的な判定基準を設定することは困 難と考学られ，性・年齢を加味する必要がある。とくに 今回の調査では，Zung 高得点の中高年男性に留意する 必要があると考えられた。

以上の結果より，Zung 自己評価式抑うつ尺度は，比 較的簡便な職場に和ける精神健康の指標のひとつとし て，また問題発見の手法として早期ケアや予防的側面に 利用できると考光た．今後，定期的な施行， follow up を通じて抑らつの構造・経過・対応のありうにも検討を 加光てゆきたい。

\section{座長の志とめ $(4,5)$}

荒井保経（聖マリアンナ医大衛生）

4 : 総括的には当然と思われる結論になったが，心身

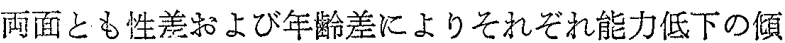
向が異なることの指摘は注目される。ただ高龄者層は， 個人差の幅がさわめて広いので，たんに平均化したもの の中で論じることの意味について，若干の疑問がもたれ る.今後低下傾向についてのみでなく，各種能力を加齢 に反してより長く維持させるための追及にも，この種の 研究が指向されることを期待したい。

5 : 職場に Zung SDS を応用して, 種々の卯らつ状 態を発見することの有効性を論じた報告である。職場に 扣ける抑らつ性には，身体的健康感，任事上の不安感之 いった因子が強く関与するという分析，判定には性差， 年撂差を配慮すべきであるといらこと，さらに得点のみ で判定基準を設定すべきではないという主張には共感て きる。この方法は使用に簡便なことから，今後急速に一 般化するものと考光られるが，あくむでむらつ状態発見
の補助的手法の域をでるものではない。むしろその範囲 内での利用に対する細かな配慮と指針の設定が望まれる ので，その方向への今後の追及を期待したい，

\section{6. 一百貨店における精神健康管理システムの開発と その現状}

成田四郎，福田笑子

（伊勢丹健康管理七）

企業内で精神健康管理を效果的にすすめるには，諸々 の条件が一体とならないと困錐をさわめ，失敗すること にもなる。肉体的健康は顕著に企柴の生麾性に影響し， また労働省からの指導もあり，急速に対策が售じられて きた，一方，精神面の健康については，多分に人間的な ことや，社会一般の偏胃などから立ち遅れている現状が ある。そこで一百貨店の精神徤康管理システム開発の一 方法とその現状について，6年を経過した段階で報告す る.

〈第一段階〉（現状把握市よび問題提起）センター開 所当時，精神疾患者が医療的かかかりがもてず，長期休 業や頻回欠勤をして和り，これらの詨処に困った人事 は，職場から他の職場へと移動をさせるのみといった現 状があった．われわれはこれらの現状をデータにまと め，上層部に提言したところ，早速，精神神経科専門医 を招請するに至った。〈第二段階〉(関係部所との連携) 把握された顕在患者を，専門医に，受潦させる万法は， むずかしく，慎重さが要求される。まず疾患者の情報に かかわり深い人事，診療所，当所のそれぞれ担当者で討 議された。 その結果われわれ担当者の知識向上，受療し やすい相談室設置，㭧者に関する情報を集め面接導入へ の方法を考える，長欠者は復職診断を行い，要保護者之 して (月 1 回面接)，フォローアップするなどが害施さ れていった。第三段階〉（潜在患者の早期発見と早期 治療）顕在患者は，ほぼ受療したが低成長の社会情勢に

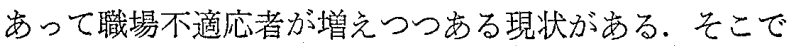
部下のマネージメントを行ら管理職に対し専門医による 講和を行い啓もうしたところである，疾病休紫日数率年 次推移は一時上昇したが低下に変わってきている，5年 を経過した現在の活動内容は講演集を参照されたい。な 特現在ようやく本人や周囲の人々が気軽に相談に訪れ問 題解決へともに考光あえるような状熊となったと判断し ている.

\section{7. 精神衛生活動と入院治療}

中村 豊（福岡大病院健康管理科）

現在の従業員数 15,000 の電力事業体を対象とする, 1957 年 4 月以降 25 年間の精神衛生活動に打いて，同期 間に在籍した從業員 27,240 の $3.1 \%$ に当たる 852 例に 
ついて専門的援助を行った．そしてその $41.9 \%$ 飞当た る 357 例は，初診時以後のある時期に，精神病院での入 院治療を経験していた。 また，各年度末に抬ける活動対 象者のなか飞留める要休養率は, 平均 $20.0 \%$ であり, その活とんどが入院治療によるるのであった。これらの 成績から，入院治療の前後のプロセスは，職場に和汁る 精神衛生活動のなかでかなり大きな比重を占めているこ とがわかる。

入院 一退院一職場復帰という一連の過程を円滑に進め るためには，職場側と治療側との継続的，かつ緊密な連 携が必要である．私の活動対象者のうちすでにのべた入 院治療経験者の $68.3 \%$ 亿当たる 244 例を担当し, 常に 数例の入院治療者之 20 例前後の通院治療者を受汗持っ ている病院とその主治医との間に，私たらは年 3 回の定 期的な連絡・協議の場を設けて掠り，精神衛生活動開始

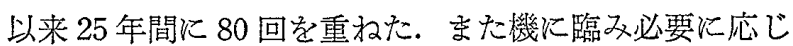
て，職場側・治療側のいずれからも，個々のケースにつ いて連絡を行っているし，円滑に意思が疎通するよう妢 めている。

このような活動を地道に積み重抆ることによって，入 院治療中の経過の把握, 職場への受け入れの準備, 各ヶ 一スに対する職場関係者の理解と受容的態度の強化な ぞ，入院治療前後の重要な時期活和る活動は，ますま す円滑化するであるう。そして職場と病院とを結ぶ liaison officer として，産業医の果たすべき役割は，き わめて大きいとい方よう。

座長のまとめ $(6,7)$

夏目 誠（阪府公衛研）

6 : 職場での身体健康管理と同様に精神健康管理の必 要性が認識され，その管理システムの 5 年間の歩みを発 表されたが，それには，職場の上司，人事担当者，相談 室のチームの共同作業が重要であることを強調された。 それはたんに精神疾患の疾病管理にとどまることなく， さらに今後は，心の健康管理に向けて，職員・家族を含 めて，いかに，進展させるかが重大な課題であり，その 一つの参考となることを示唆している.

7 は，ある企業に和讬る 25 年間の精神衛生活動対象 者 852 名のうち， $41.2 \%$ が入院して和り，それを踏竞え て健康管理医の役割として, 病院と職場を結ら゙ liaison officer，とくに復職時に郝ける主治医々職場の意見のズ レの調整が重要であることを示した. 病院との協議会に 関して，そのメンバー，所属長がふくまれているかの 2 問の質問があった。出席者は, 主治医, 健康管理医, 保 健婦, 衛生管理者で所属長は出席しないとの答であっ た.

\section{8. 職場不適応症について（第与報）女性職員症例を 中心として}

夏目 誠，藤井久和（阪府公衛研精神衛生） 南野寿重（阪大医精神） 浅尾博一（阪府中宮病院）

最近 13 年間に公衛研精神衛生部外来を受診した女泩 の職場不適応症者 32 名について，調查を行った.

得られた結果は以下のと赫りである。

1）代表的な症例を呈示し，考察を加えた.

2）年度別推移では，50 年度から漸增傾向にあり, $55 ， 56$ 年度は各 7 名と多くに認められた。

3）高学歷を有する 20 歳代の未婚の女性で事務作業 者と専門職洼事する者に多く発生していた。

4）発症要因として，職場要因では，対人関係や尃門 職への適性が不十分であったことに起因する者が多く認 められ，性格傾向では，未熟で自己中心的な者と，小心 で神経質な者が多かった。

5 ）代表的なタイプである中核群は 3 名にすざず，対 人関係を主とする一過性反応群が 13 名と多く認められ た.

6）男性職員との差異については，管理職，経営者な ぞの大部分を男性が占め，職務内容に括いても男性主導 型の日本の産業構造が大きく関係していると考兄た。 た，対人関係起因性のものが女性に多いのは，通常男性 に比べて女性は配置転換が少なく，同一職場に長年勤務 するといら要因も関与していると推察した.

9. 職場不適応症について (第 6 報) 中核群とドロッ プアウト群の精神生理指標の比較

太田義隆，夏目 誠，藤本 修 藤井久和（阪府公衛研精神衛生） 南野寿重（阪大医精神） 浅尾博一（阪府中宫病院）

最近，識場勤務者が職場の諸要因に適切に対応できず 就業困難となり，抑うつ・不安・焦燥感などを訴兄る職 場不適応症 (OMAS) の增加がみられ，職場の精神衛生 上大きな関心がもたれている。われわ机は OMAS の病 態を明らか沉するため精神生理学的特徵について検討し てきた. 今回，OMAS の代表的な中核群，ドロップア ウト群について, 覚醒水準や心的緊張と関係が深い眼球 運動，情動の指標である表情筋筋電図などの生理学的指 標を用い，OMAS の病態発生機序について考察し沈の で報告する。

対象は，精神障害により二次的に発症した不適応を除 外した OMAS の中核群 25 名 (平均 40.2 歳), ドロッ プアウト群 14 名 (31.5 歳), 正常対照群 16 名 (29.1 歳) 